\title{
Retrieval Efficiency of Search Engines on Medical Tourism in Kerala: A Webometric Analysis
}

Thanuskodi S, Naseehath S

Alagappa University

Karaikudi

India

ABSTRACT: World Wide Web is like an ocean of information; it is not easy to find specific information from it because the web is very huge and growing all the time. So there are certain tools used to search information from the web. They are called search engines. They search through all the web sites and create an index of the information of the web sites and act as a single point to find relevant information. E.g. Google, Yahoo, Bing, Lycos, Info seek etc. Analysis on 8 representative variables form all the subsectors of on Medical Tourism in Kerala, the search engine Lycos retrieves 59\% of the total results and stands first followed by Bing in the second position with $37 \%$ and Google in third position with only $2 \%$ of results. The remaining less than $1 \%$ is shared by all Metasearch engines, of these Ixquick stands first with a slight difference from others followed by Dogpile and WebCrawler Analysis of 10 variables on Ayurveda tourism Lycos occupies first place with a high result of $85 \%$ and Google in the second position followed by Bing in the third position with a less Percentage of 7 and 6 respectively. Among Metasearch engines Ixquick stands first, followed by WebCrawler and Dogpile.

Keywords: Search Engines, Retrieval Efficiency, Medical Tourism, Webometrics, Internet

Received: 19 February 2019, Revised 4 April 2019, Accepted 8 May 2019

DOI: $10.6025 /$ jism/2019/9/3/91-99

(C) 2019 DLINE. All Rights Reserved

\section{Introduction}

Webometric covers research of all network based on communications using informetric or other qualitative measures. Its methodology draws especially from bibliometrics. It is clear that informetric methods using word counts and similar techniques can be regarded as a citation network, where the traditional information entities and citations from them are replaced by web pages. These pages are the entities of information on the web with hyperlinks from them acting as citations. The use of info metric methods on www allows the analysis to be similar way as in the traditional citation database. Studies in webometrics focus on hyperlinks as a potential source of new information. The retrieval efficiency of a search engine means the efficiency to retrieve more documents on a particular query. The variables selected for the key word searching are grouped into ten categories of sub headings in the topic Medical Tourism in Kerala for the analysis of retrieval efficiency of search engines as follows.

Journal of Information \& Systems Management Volume 9 Number 3 September 2019 
1) Medical Tourism in Kerala

2) Ayurveda Tourism in Kerala

3) Dental Tourism in Kerala

4) Fertility Tourism in Kerala

5) AYUSH in Kerala

6) Medical Tourism Hospitals in Kerala

7) IVF Hospitals in Kerala

8) Ayurveda Centers in Kerala

\section{Review of Literature}

Bharat and Border (1998) measured overlap among websites indexed by Hotbot, Altavista, Excite, and Infoseek using 10,000 queries carried out at two different intervals of time in June 1999 and November 1999, and found that the overlap was very small, less than 1.4 percent of the total coverage. Chowdhury(2002) introduced search engines and explains at some length how they operate, highlighting their strength and weakness. It gave a useful overview of the range of resource available, and provided a good grounding on the technique and principles involved in information retrieval on the web. Ding and Marchionini (1996) studied Infoseek, Lycos and Open Text for precision, duplication and degree of overlap using five complex queries. The first twenty hits assessed for precision show that the best results were obtained from Lycos and Open Text. Leighton and Srivastava (1997) conducted a study to compare five search engines for precision on the first 20 results returned for 15 queries. Analysis shows that AltaVista, Excite and Infoseek are top three services. Clarke and Willett (1997) searched thirty queries of varying nature on AltaVista, Excite and Lycos and obtained best results in terms of precision, recall and coverage from AltaVista. Bar-Ilan (1998) investigated six search engines using a single query "Erdos". All 6,681 retrieved hits examined for precision, overlap and an estimated recall reported that no search engine had high recall. Chignell, Gwizdka, and Bonder (1999) found little overlap in the results returned by various search engines and describe meta?search engines as useful.

\section{Objectives of the Study}

To ascertain the various types and quantities of information resources accessible through World Wide Web in the field of Medical Tourism in Kerala.

To compare and evaluate the relative efficiency of six search engines that is three general search engines with three Metasearch engines. Bing, Google, Lycos with Dogpile, Ixquick and WebCrawler in locating the web resources on Medical Tourism in Kerala and thereby identify and select relevant search engine in this field.

To compare and evaluate the above search engines on the basis of their precision and recall.

To find out the rate of stability of search results of these search engines.

\section{Methodology}

Methodology used for the study is the webometric study. Six search engines namely Bing, Google, Lycos, and Dogpile, Ixquick and WebCrawler are used to collect relevant information from the web. For it different variables on the topic Medical Tourism in Kerala are selected for key word searching. Quantitative analysis is done on these results for each search engine. Search on each category is done simultaneously due to the dynamic nature of the web.

\section{Data Analysis}

$92 \quad$ Journal of Information \& Systems Management Volume 9 Number 3 September 2019 
For analysis of Retrieval efficiency of search engines on Medical Tourism in Kerala 10 representative variable from different sub sectors of Medical Tourism are selected as key words. Search was conducted on 26 th September 2014 and number of hits retrieved for each query by all the six search engines were noted. The key words used and number of hits retrieved by each search engines are as shown in table 1.

\begin{tabular}{|c|c|c|c|c|c|c|c|c|}
\hline \multirow{2}{*}{ No. } & \multirow{2}{*}{ Keywords } & \multicolumn{3}{|c|}{ Search Engines } & \multicolumn{3}{|c|}{ Metasearch Engines } & \multirow{2}{*}{ Total } \\
\hline & & Bing & Google & Lycos & Dogpile & Ixquick & \begin{tabular}{|c|} 
Web \\
Crawler
\end{tabular} & \\
\hline 1 & Medical Tourism & 8980000 & 1240000 & 4330000 & 630 & 853580 & \begin{tabular}{|l|l|}
270 \\
\end{tabular} & 15404480 \\
\hline 2 & Health Tourism & 5080000 & 2950000 & 3260000 & 570 & 539420 & 490 & 11830480 \\
\hline 3 & Ayur-veda Tourism & 1920000 & 2360000 & 140000 & 640 & 687789 & 530 & 6108959 \\
\hline 4 & Dental Tourism & 320000 & 443000 & 281000 & 230 & 238659 & 210 & 1283099 \\
\hline 5 & $\begin{array}{l}\text { Med.Tour.Hospita- } \\
\text { ls }\end{array}$ & 62500000 & 1720000 & 67300000 & 530 & 303893 & 450 & 131824873 \\
\hline 6 & Med. Trav.Agen. & 44500000 & 403000 & 65100000 & 650 & 295999 & 490 & 110300139 \\
\hline 7 & Med. Travel Comp. & 46700000 & 222000 & 88400000 & 710 & 203057 & 530 & 135526297 \\
\hline 8 & Med.Tour. Packages & 48700000 & 719000 & 58400000 & 670 & 308852 & 530 & 108129052 \\
\hline 9 & Cost of Treat. & 1860000 & 308000 & 60100000 & 250 & 230813 & 210 & 62499273 \\
\hline 10 & Jobs and Carriers & 2500000 & 421000 & 3630000 & 280 & 414461 & 210 & 6965951 \\
\hline \multicolumn{2}{|c|}{ Total } & 223060000 & 10786000 & 351941000 & 5160 & 4076523 & 3920 & \multirow[t]{2}{*}{589872603} \\
\hline \multicolumn{2}{|c|}{ Percentage } & 37.814 & 1.828 & 59.663 & 0.0008 & 0.691 & 0.0006 & \\
\hline
\end{tabular}

Table 1. Retrieval efficiency of search engines on Medical Tourism in Kerala

On analysis it is found that number of hits retrieved for a particular key word varies with search engines. Further number of hits retrieved by Metasearch engines is very less, even negligible, when compared to that of general search engines. The table 1 shows that a total of 589872603 hits were retrieved by all the six search engines, of these Lycos shows high retrieval efficiency with 351941000 (59.66\%) sites followed by Bing in the second position with 223060000 (37.81\%) sites and Google with 10786000 $(1.82 \%)$ sites and stands at the third position and the remaining less than $1 \%$ is shared by all the three Metasearch engines. Of these Ixquick stands first with a slight difference from others followed by Dogpile and WebCrawler.

Ten variables under the sub sector Ayurveda tourism is used to collect the results from six search engines. The variables used as key words are as shown in Table 2. On analysis it is found that a total of 44473380 sites were retrieved by all six search engines. Here also Lycos shows very high retrieval efficiency with 38023900 (85.49\%) sites followed by Google and Bing with 7.87\% and $6.59 \%$ of results respectively. Among Metasearch engines Ixquick stands first with $0.012 \%$ of total sites followed by WebCrawler and Dogpile.

Ten variables under the sub division Dental tourism in Kerala are used as key words and results are noted as given in Table 3. On analysis it is found that Search engine Google retrieved 5269200 sites out of a total of 11403330 sites and attains first with 46.20 $\%$ of results. Here Lycos comes second with 34.89\% followed by Bing with 18.80\%. Among Metasearch engines Ixquick stands first $0.042 \%$ followed by Dogpile and WebCrawler. 


\begin{tabular}{|c|c|c|c|c|c|c|c|c|}
\hline \multirow[b]{2}{*}{ No. } & \multirow[b]{2}{*}{ Keywords } & \multicolumn{4}{|c|}{ Search engines } & \multicolumn{2}{|c|}{$\begin{array}{c}\text { Metasearch } \\
\text { Engines }\end{array}$} & \multirow[t]{2}{*}{ Total } \\
\hline & & Bing & Google & Lycos & $\begin{array}{l}\text { Dog } \\
\text {-pile }\end{array}$ & $\begin{array}{l}\text { Ixquic } \\
\mathbf{k}\end{array}$ & $\begin{array}{l}\text { WebCra- } \\
\text { wler }\end{array}$ & \\
\hline 1 & Ayurveda Tourism & 767000 & 704000 & 2100000 & 310 & 640 & 410 & 3572360 \\
\hline 2 & Ayurveda Centres & 375000 & 454000 & 446000 & 590 & 500 & 480 & 1276570 \\
\hline 3 & Ayurveda Packages & 278000 & 371000 & 447000 & 350 & 850 & 600 & 1097800 \\
\hline 4 & Ayurveda Treatments & 333000 & 433000 & 194000 & 330 & 740 & 270 & 961340 \\
\hline 5 & $\begin{array}{l}\text { Pizhichil,Njavara., } \\
\text { Dhaara,Mass. }\end{array}$ & 6930 & 84300 & 64900 & 290 & 710 & 470 & 157600 \\
\hline 6 & Rasayana Chikitsa & 46300 & 9400 & 125000 & 410 & 570 & 380 & 182060 \\
\hline 7 & Sweda Karma & 1940 & 48000 & $\begin{array}{l}1270900 \\
280\end{array}$ & 140 & 210 & 0 & 1271637 \\
\hline 8 & Pancha karma & 118000 & 3380000 & 1100000 & 280 & 570 & 4400 & 1145729 \\
\hline 9 & Yoga\& Meditation & 283000 & 2390000 & 1010000 & 310 & 350 & 2500 & 1062311 \\
\hline \multirow[t]{3}{*}{10} & SPA Resorts & 725000 & 865000 & 838000 & 230 & 460 & 390 & 2429080 \\
\hline & Total & $\begin{array}{l}293417 \\
0\end{array}$ & $\begin{array}{l}3502500 \\
0\end{array}$ & $\begin{array}{l}3802390 \\
0\end{array}$ & 3380 & 5530 & 3900 & \multirow[t]{2}{*}{44473380} \\
\hline & Percentage & 6.598 & 7.875 & 85.498 & .008 & .012 & .009 & \\
\hline
\end{tabular}

Table 2. Retrieval efficiency of search engines on Ayurveda tourism in Kerala

Five variables in the topic Fertility tourism are selected as key words and number of hits by all six search engines was noted as in Table 4. On analysis it is found that from a total of 25727150 sites Bing retrieved 15485400 sites with $60.19 \%$ followed by Lycos with $34.50 \%$ and Google with $5.27 \%$ of results. Here also Metasearch engine Ixquick stands first among them followed by WebCrawler and Dogpile.

AYUSH is an acronym of Ayurveda, Yoga and Naturopathy, Unani, Siddha and Homeopathy. Government of Kerala, with an aim to give a boost to traditional systems of medicines and incorporate them in the prevention and treatment of diseases, launched its AYUSH department on 5th August, 2015. The proposed department, designed on the model of the Centre's AYUSH department, is envisaged to focus on treatment, research and education in Ayurveda, Yoga, Unani, Siddha and Homoeopathy. Five components of AYUSH are selected for the key word searching and number of hits retrieved by six search engines was tabulated as in Table 5. On analysis it is found that search engine Lycos retrieved 33285000 sites with $50.47 \%$ from a total of 65941370 sites followed by Bing with $46.23 \%$ and Google with 3.28\%. Among the Metasearch engines Dogpile stands first with $0.004 \%$ of total results followed by Ixquick and WebCrawler.

A number of Medical Tourism hospitals are there in Kerala. Ten hospitals selected from the top pages of all the six search engines were used to evaluate the retrieval efficiency of search engines on Medical Tourism hospitals. AIMS- Kochi, AnanthapuriTrivandrum, Aster Medcity- Kochi, Indo American Hospital- Vaikom, KIMS- Trivandrum, Lakeshore- Kochi, Medical TrustKochi and Trichur Heart Hospital- Thissure are the selected hospitals and used as key words. Numbers of hits retrieved for each 


\begin{tabular}{|c|c|c|c|c|c|c|c|c|}
\hline \multirow[t]{2}{*}{ No. } & \multirow[t]{2}{*}{ Keywords } & \multicolumn{3}{|c|}{ Search engines } & \multicolumn{3}{|c|}{ Metasearch engines } & \multirow[t]{2}{*}{ Total } \\
\hline & & Bing & Google & Lycos & Dogpile & Ixquick & Webcra & \\
\hline 1 & Dental Tourism & 194000 & 455000 & 195000 & 270 & 430 & 330 & 845030 \\
\hline 2 & Dental Clinics & 191000 & 1040000 & 186000 & 270 & 420 & 360 & 1418050 \\
\hline 3 & $\begin{array}{l}\text { Dental tourism } \\
\text { Packages }\end{array}$ & 143000 & 870000 & 114000 & 290 & 590 & 240 & 1128120 \\
\hline 4 & $\begin{array}{l}\text { Dental } \\
\text { Treatments }\end{array}$ & 201000 & 392000 & 191000 & 300 & 540 & 450 & 785290 \\
\hline 5 & $\begin{array}{l}\text { Cosmetic } \\
\text { Dentistry }\end{array}$ & 34300 & 87200 & 50500 & 270 & 520 & 250 & 172840 \\
\hline 6 & Dental Studios & 122000 & 650000 & 294000 & 300 & 400 & 290 & 1066990 \\
\hline 7 & $\begin{array}{l}\text { Smile } \\
\text { Designers }\end{array}$ & 321000 & 825000 & 320000 & 310 & 520 & 400 & 1467230 \\
\hline 8 & $\begin{array}{l}\text { Dental } \\
\text { Implants }\end{array}$ & 24400 & 109000 & 20200 & 250 & 300 & 350 & 154500 \\
\hline 9 & Orthodontics & 32100 & 619000 & 38100 & 300 & 560 & 410 & 690470 \\
\hline 10 & $\begin{array}{l}\text { Root canal } \\
\text { Treatments }\end{array}$ & 881000 & 222000 & 2570000 & 820 & 550 & 240 & 3674610 \\
\hline & Total & 2143800 & 5269200 & 3978800 & 3380 & 4830 & 3320 & 11403330 \\
\hline & Percentage & 18.800 & 46.208 & 34.891 & .030 & .042 & .029 & \\
\hline
\end{tabular}

Table 3. Retrieval efficiency of search engines on Dental tourism in Kerala

hospital by all six search engines were noted. Analysis shows that search engines Lycos and Bing retrieved almost same amount of hits with $46.90 \%$ and $46.26 \%$ respectively. As usual Google shows only a less amount of hits with $6.78 \%$ of results. Among Metasearch engines Ixquick comes first with $0.016 \%$ followed by WebCrawler and Dogpile as shown in Table 6.

Kerala is becoming one of the fertility tourism hubs of South India having a number of infertility clinics with world class facilities at affordable expense. IVF means In Vitro Fertilization which is an advanced reproductive technique. Hospital having infertility treatments are commonly called IVF hospitals. Five popular IVF hospitals selected from the top pages of six search engines were used as key words for finding retrieval efficiency of search engines on them. ARMC-Kozhikode, CRAFT Hospital- Thrissur, GIFTGyno IVF- Kochi, Lifeline Hospital-Adoor and Samad IVF- Trivandrum were the selected hospitals for the study. A total of 2764280 hits were retrieved by all the six search engines, of these Lycos stands first with 1408500 hits with $50.95 \%$ followed by Bing with $46.17 \%$ and Google at far behind with only $2.69 \%$ of hits. Here also Metasearch engine Ixquick comes first among them followed by Dogpile and WebCrawler as shown in Table 7.

Kerala is known as the land or home of Ayurveda and treatment centers are known by name resorts, hospitals, vydyasalas, clinics, spas, massage centers, ayurveda parlors etc; .Ayurveda tourism centers are there in all the 14 districts of Kerala. Here only five 


\begin{tabular}{|l|l|l|l|l|l|l|l|l|}
\hline \multirow{2}{*}{ No. } & \multirow{2}{*}{ Keywords } & \multicolumn{2}{|c|}{ Search Engines } & \multicolumn{2}{|l|}{ Metasearch Engines } & \\
\cline { 3 - 9 } & Bing & Google & Lycos & Dogpile & $\begin{array}{l}\text { Ixqui- } \\
\text { ck }\end{array}$ & $\begin{array}{l}\text { Web } \\
\text { Crawler Total }\end{array}$ \\
\hline 1 & $\begin{array}{l}\text { Fertility } \\
\text { Tourism }\end{array}$ & 3070000 & 601000 & 3330000 & 230 & 550 & 450 & 7002230 \\
\hline 2 & $\begin{array}{l}\text { Reproductive } \\
\text { Tourism }\end{array}$ & 2180000 & 469000 & 2150000 & 210 & 560 & 440 & \multirow{2}{*}{4800210} \\
\hline 3 & $\begin{array}{l}\text { Surrogacy } \\
\text { Tourism }\end{array}$ & 9880000 & 143000 & 2950000 & 430 & 510 & 460 & 12974400 \\
\hline 4 & IVF & 310000 & 81600 & 261000 & 580 & 480 & 530 & 654190 \\
\hline 5 & Neonatology & 45400 & 62400 & 187000 & 510 & 420 & 390 & 296120 \\
\hline & Total & 15485400 & 1357000 & 8878000 & 1910 & 2520 & 2270 & 25727150 \\
\cline { 2 - 9 } & Percentage & 60.190 & 5.274 & 34.508 & .007 & .009 & .008 & \\
\hline
\end{tabular}

Table 4. Retrieval efficiency of search engines on Fertility tourism in Kerala

\begin{tabular}{|c|c|c|c|l|l|l|l|l|}
\hline \multirow{2}{*}{ No. } & \multirow{2}{*}{ Keywords } & \multicolumn{4}{|c|}{ Search Engines } & \multicolumn{4}{c|}{ Metasearch Engines } \\
\cline { 3 - 9 } & & Bing & Google & Lycos & Dogpile & $\begin{array}{l}\text { Ixqui- } \\
\text { ck }\end{array}$ & $\begin{array}{l}\text { Web } \\
\text { Crawler }\end{array}$ & Total \\
\hline 1 & AYUSH & 9630000 & 425000 & 10500000 & 570 & 350 & 330 & 20556250 \\
\hline 2 & $\begin{array}{c}\text { Yoga \& } \\
\text { Naturopathy }\end{array}$ & 1090000 & 219000 & 1350000 & 690 & 580 & 510 & 2660780 \\
\hline 3 & Unani & 9800000 & 433000 & 10800000 & 590 & 550 & 390 & 21034530 \\
\hline 4 & Siddha & 9790000 & 536000 & 10500000 & 570 & 520 & 370 & 20827460 \\
\hline 5 & Homeopathy & 176000 & 550000 & 135000 & 450 & 500 & 400 & 862350 \\
\hline & Total & 30486000 & 2163000 & 33285000 & 2870 & 2500 & 2000 & $\mathbf{6 5 9 4 1 3 7 0}$ \\
\cline { 2 - 9 } & Percentage & 46.231 & 3.280 & 50.476 & .004 & .003 & .003 & \\
\hline
\end{tabular}

Table 5. Retrieval efficiency of search engines on AYUSH in Kerala

famous and well established Ayurveda centers in Kerala namely Dhanvanthari, Dhathri, Kottakkal, Nagarjuna and Somatheeram Ayurveda centers are taken as the key words for collecting web resources by six search engines. On analysis it is found that a total of 1591900 sites were retrieved by all the six search engines and Google stands first with 963000 sites with $60.49 \%$ followed by Lycos with $22.90 \%$ of results and Bing with $16.27 \%$. Among the Metasearch engines Ixquick stands first as usual followed by WebCrawler and Dogpile as shown in Table 8. 


\begin{tabular}{|c|c|c|c|c|c|c|c|c|}
\hline \multirow[t]{2}{*}{ No. } & \multirow[t]{2}{*}{ Keywords } & \multicolumn{3}{|c|}{ Search Engines } & \multicolumn{4}{|c|}{ Metasearch Engines } \\
\hline & & Bing & Google & Lycos & $\begin{array}{l}\text { Dog- } \\
\text { pile }\end{array}$ & $\begin{array}{c}\text { Ixqui- } \\
\text { ck }\end{array}$ & $\begin{array}{l}\text { Web } \\
\text { Crawler }\end{array}$ & Total \\
\hline 1 & $\begin{array}{l}\text { AIMS, } \\
\text { Kochi }\end{array}$ & 955000 & 664000 & 958000 & 530 & 510 & 390 & 2578430 \\
\hline 2 & $\begin{array}{l}\text { Ananthapuri } \\
\text { Trivandrum }\end{array}$ & 8640 & 21100 & 13600 & 250 & 340 & 280 & 44210 \\
\hline 3 & $\begin{array}{l}\text { Aster } \\
\text { Medcity, } \\
\text { Kochi }\end{array}$ & 11700 & 30300 & 11600 & 300 & 330 & 370 & 54600 \\
\hline 4 & $\begin{array}{l}\text { Indo-Amer. } \\
\text { Hospital, } \\
\text { Vaikom }\end{array}$ & 2130 & 7130 & 2140 & 320 & 420 & 290 & 124300 \\
\hline 5 & $\begin{array}{l}\text { KIMS, } \\
\text { Trivandrum }\end{array}$ & 27800 & 97000 & 27800 & 290 & 310 & 300 & 153500 \\
\hline 6 & $\begin{array}{l}\text { Lakeshore, } \\
\text { Kochi }\end{array}$ & 40700 & 53300 & 40700 & 530 & 540 & 480 & 136250 \\
\hline 7 & $\begin{array}{l}\text { Medi.Trust, } \\
\text { Kochi }\end{array}$ & 111000 & 157000 & 111000 & 310 & 330 & 360 & 380000 \\
\hline 8 & $\begin{array}{l}\text { MIMS, } \\
\text { Kottakkal }\end{array}$ & 4350 & 15500 & 4220 & 290 & 310 & 300 & 24970 \\
\hline 9 & $\begin{array}{l}\text { Specialists } \\
\text { Hospital, } \\
\text { Kochi }\end{array}$ & 9500000 & 488000 & 9690000 & 410 & 500 & 430 & 19679340 \\
\hline 10 & $\begin{array}{l}\text { Trichur } \\
\text { Heart } \\
\text { Hospital }\end{array}$ & 89300 & 43100 & 40300 & 310 & 320 & 360 & 173690 \\
\hline & Total & 10750620 & 1576430 & 10899360 & 3540 & 3910 & 3560 & 23237420 \\
\hline & Percentage & 46.264 & 6.784 & 46.904 & .015 & .016 & .015 & \\
\hline
\end{tabular}

Table 6. Retrieval efficiency of search engines on Medical Tourism hospitals in Kerala

\section{Conclusion}

Medical Tourism in Kerala is an emerging field with a number of best hospitals, their infrastructure facilities, cost effective medical treatments and well trained human resources. But printed documents and reference sources are very less in this topic. Nascent information in primary sources are scattered in the journals of various disciplines like tourism, medicine business, economics, management etc. due to its multidisciplinary nature. But there are a number of web sources in the World Wide Web on Medical Tourism in Kerala. The exponential growth of the web resources propelled the rapid development of the web search engines which 


\begin{tabular}{|c|c|c|c|c|c|c|c|c|}
\hline \multirow[t]{2}{*}{ No. } & \multirow[t]{2}{*}{ Keywords } & \multicolumn{3}{|c|}{ Search Engines } & \multicolumn{4}{|c|}{ Metasearch Engines } \\
\hline & & Bing & Google & Lycos & $\begin{array}{c}\text { Dog- } \\
\text { pile }\end{array}$ & $\begin{array}{c}\text { Ixqui- } \\
\text { ck }\end{array}$ & $\begin{array}{l}\text { Web } \\
\text { Crawler }\end{array}$ & Total \\
\hline 1 & $\begin{array}{l}\text { ARMC, } \\
\text { Kozhikode }\end{array}$ & 19900 & 5450 & 64200 & 340 & 310 & 330 & 90530 \\
\hline 2 & $\begin{array}{l}\text { CRAFT } \\
\text { Hosp.Tsr. }\end{array}$ & 1060000 & 44400 & 1070000 & 470 & 500 & 410 & 2175780 \\
\hline 3 & $\begin{array}{l}\text { GIFT?Gyno IVF, } \\
\text { Kochi }\end{array}$ & 132000 & 8830 & 132000 & 310 & 330 & 300 & 273770 \\
\hline 4 & $\begin{array}{l}\text { Lifeline } \\
\text { Hosp.Adr. }\end{array}$ & 32200 & 9850 & 32300 & 270 & 340 & 280 & 75240 \\
\hline 5 & $\begin{array}{l}\text { Samad } \\
\text { IVF, } \\
\text { Trivandrum }\end{array}$ & 32200 & 5960 & 110000 & 220 & 330 & 250 & 148960 \\
\hline & Total & 1276300 & 74490 & 1408500 & 1610 & 1810 & 1570 & 2764280 \\
\hline & Percentage & 46.171 & 2.694 & 50.953 & .058 & .065 & .056 & \\
\hline
\end{tabular}

Table 7. Retrieval efficiency of search engines on IVF hospitals in Kerala

\begin{tabular}{|c|l|l|l|l|l|l|l|l|}
\hline \multirow{2}{*}{ No. } & \multirow{2}{*}{ Keywords } & \multicolumn{3}{|c|}{ Search Engines } & \multicolumn{3}{|c|}{ Metasearch Engines } \\
\cline { 3 - 8 } & & Bing & Google & Lycos & $\begin{array}{c}\text { Dog- } \\
\text { pile }\end{array}$ & $\begin{array}{c}\text { Ixqui- } \\
\text { ck }\end{array}$ & $\begin{array}{c}\text { Web } \\
\text { Crawler }\end{array}$ & Total \\
\hline 1 & $\begin{array}{l}\text { Dhanvanthari } \\
\text { Ayurveda }\end{array}$ & 106000 & 123000 & 114000 & 370 & 720 & 570 & 344660 \\
\hline 2 & $\begin{array}{l}\text { Dhathri } \\
\text { Ayurveda }\end{array}$ & 17500 & 113000 & 30500 & 190 & 290 & 250 & 161730 \\
\hline 3 & $\begin{array}{l}\text { Kottakkal } \\
\text { Ayurveda }\end{array}$ & 51300 & 257000 & 64100 & 340 & 350 & 330 & 373420 \\
\hline 4 & $\begin{array}{l}\text { Nagarg. } \\
\text { Ayurveda }\end{array}$ & 40600 & 361000 & 61600 & 260 & 450 & 410 & 464320 \\
\hline 5 & $\begin{array}{l}\text { Somath. } \\
\text { Ayurveda }\end{array}$ & 43700 & 109000 & 94400 & 230 & 270 & 170 & 247770 \\
\hline & Total & 259100 & 963000 & 364600 & 1390 & 2080 & 1730 & 1591900 \\
\hline
\end{tabular}

Table 8. Retrieval efficiency of search engines on Ayurveda Centers in Kerala 
are the most effective tools to access information on various topics. They retrieve a huge amount of information with a number of irrelevant sites. In this study search engines and Metasearch engines are at two extremes in their retrieval efficiency, but their precisions are at the same range. Even though Metasearch engines show very low relative recall, their precision is same as that of search engines with high relative recall. Webometric studies on search engines are manifold, which provide some inputs to web site developers as well as search engine designers to make the search engines more capable.

\section{References}

[1] Bar-Ilan (1998). On the overlap, the precision and estimated recall of search engines: A case study of the query "Erdos". Scientometrics,42(2) 207-208

[2] Bharat, K., \& Broder, A. (1998). A technique for measuring the relative size and overlap of public Web search engines. Computer Networks and ISDN Systems, 30 (1-7) 379-388.

[3] Chignell, M. H., Gwizdka, J., Bodner, R. C. (1999). Discriminating meta-search: A framework for evaluation. Information Processing and Management, 35, 337-362.

[4] Chowdhury, G. G. (2002). Information sources and searching on the World Wide Web. Program, 36 (3) 206.

[5] Clarke, S. and Willett, P. (1997). Estimating the recall performance of search engines. ASLIB Proceedings, 49 (7) 184-189.

[6] Ding, W., Marchionini, G. (1996). A comparative study of the Web search service Performance. In: Proceedings of the ASIS 1996 Annual Conference, October, 33, 136-142.

[7] Leighton, H. and Srivastava, J. (1997).Precision among WW search services (search engines ): Alta Vista, Excite, HotBot, Infoseek and Lycos. Retrieved December 15, 2014 from http://www.winona.edu/library/webind.htm. 